\title{
Pawel Tomanek*
}

Uniwersytet Warszawski

\section{Kaja Rożdżyńska-Stańczak}

\author{
Uniwersytet Warszawski
}

\section{POTRZEBY CZY ZASOBY? \\ NURTY DIAGNOZOWANIA KULTURY NA POZIOMIE GMIN}

\begin{abstract}
W artykule omawiamy wybrane wyniki badań poświęconych praktykom diagnozowania kultury na poziomie gmin. Rozróżniamy dwie ogólne perspektywy, z których bada się i opisuje uczestników kultury oraz ich relacje z instytucjami kulturalnymi. Perspektywa potrzeb uczestników oznacza w praktyce badanie ich preferencji kulturalnych i oczekiwań odnośnie do działalności instytucji. Implikuje to ,jednowymiarowe” ujęcie kulturalnych potrzeb i sprowadza uczestników do roli odbiorców oferty instytucjonalnej. Perspektywa zasobów uczestników kładzie nacisk na ich indywidualne cechy i zbiorowe formy kapitału, które sprzyjają aktywności kulturalnej. Takie podejście przekłada się na bardziej podmiotowe ujęcie uczestników, których postrzega się w większym stopniu jako potencjalnych partnerów instytucji i współtwórców lokalnej kultury.
\end{abstract}

Słowa kluczowe: lokalna diagnoza kultury, potrzeby kulturalne, zasoby uczestników kultury

\section{WPROWADZENIE}

Od kilku lat możemy zaobserwować wzrost popularności różnego rodzaju „diagnoz kultury” - badań aktualnego stanu życia kulturalnego na danym obszarze (województwa, gminy, pojedynczej miejscowości), które mają dostarczać przesłanek do planowania działań kulturalnych przez samorządy i poszczególne instytucje. Niektórzy badacze (np. Bachórz 2014) wiążą tę tendencję z Kongresem Kultury z 2009 roku, który przekonał część decydentów, że „kultura ma znaczenie”, a przynajmniej spopularyzował (względnie) nowy dyskurs na jej temat, podkreślający społeczne i ekonomiczne korzyści płynące z działań kulturalnych. Problematyka diagnoz kultury doczekała się też pierwszego od ponad trzydziestu lat polskiego opracowania akademickiego - niedawno ukazała się praca zbiorowa Diagnoza w kulturze (Krajewski i Skórzyńska 2017), której autorzy omawiają nie tylko praktyczne zagadnienia

* Adres do korespondencji: Paweł Tomanek, Instytut Stosowanych Nauk Społecznych, Uniwersytet Warszawski, ul. Nowy Świat 69,00-927 Warszawa; e-mail: pawel.tomanek@uw.edu.pl. 
związane z procesem diagnozowania, ale też jego głębsze implikacje metodologiczne i ideologiczne. Przybywa także diagnoz realizowanych przez profesjonalnych badaczy o zapleczu socjologicznym i antropologicznym. Raporty z tych badań są najczęściej powszechnie dostępne w sieci (np. Bargielski i Wittels 2014; Theiss et al. 2009), dzięki czemu mogą się stać punktem odniesienia dla kolejnych prób podejmowanych w tej dziedzinie. Należy się więc spodziewać, że „boom diagnostyczny” przybierze na sile, ponieważ zwłaszcza na poziomie gmin daleko tu jeszcze do nasycenia. Można też mieć nadzieję, że rozwój metodologii i wspomniane przykłady „dobrych praktyk” doprowadzą do dalszej profesjonalizacji diagnoz, zwłaszcza tych realizowanych w małej skali, a więc w gminach i miejscowościach.

Rosnącemu zainteresowaniu diagnozowaniem kultury nie towarzyszy jednak obszerniejsza wiedza na temat tego, jak wyglądają już zrealizowane diagnozy - jaki był ich zakres tematyczny, jakie narzędzia badawcze w nich wykorzystano, jakie rekomendacje przedstawiono odbiorcom badań. Jedyne dostępne podsumowanie - Raport o raportach o kulturze Tomasza Szlendaka i Krzysztofa Olechnickiego (2016) - skupia się na badaniach ogólnopolskich lub prowadzonych w skali województw, często poświęconych określonej dziedzinie kultury, i rozpatruje je przede wszystkim pod kątem sposobu komunikowania wyników. Lukę tę próbowaliśmy uzupełnić w badaniach prowadzonych przez zespół Fundacji Obserwatorium Żywej Kultury - Sieci Badawczej, finansowanych przez Ministerstwo Kultury i Dziedzictwa Narodowego w ramach programu „Obserwatorium kultury”. Ich celem było określenie, w jakim stopniu diagnozy kultury są uwzględniane przy podejmowaniu decyzji dotyczących form działalności kulturalnej w gminie i jakie czynniki na to wpływają. Na pierwszym etapie badań przeanalizowaliśmy celową próbę pięćdziesięciu siedmiu dokumentów diagnostycznych z czterdziestu sześciu gmin lub dzielnic wielkich miast² ${ }^{2}$ aby zrekonstruować przyjętą w nich wizję kultury i relacji między jej uczestnikami a instytucjami kulturalnymi.

Analiza doprowadziła nas między innymi do wniosku, że w lokalnych diagnozach kultury można wyróżnić dwa niewykluczające się empirycznie, ale odrębne analitycznie nurty - diagnozowanie potrzeb i diagnozowanie zasobów. Ten pierwszy nurt można uznać za „tradycyjną” formę diagnoz, dobrze zakorzenioną w dyskursie instytucji i praktyce badawczej, chociaż - jak spróbujemy pokazać - często nieposiadającą wyraźnego zaplecza teoretycznego. Co więcej, diagnozy spod znaku „badania potrzeb kulturalnych”, mimo że z założenia są otwarte na „głosy uczestników”, w rzeczywistości prowadzą do przyjęcia dosyć paternalistycznej wizji relacji między nimi a instytucjami kulturalnymi. Drugi nurt diagnozowanie zasobów - wpisuje się w nieco nowsze ujęcie zasad i celów działalności kulturalnej. Jest on wolny od niektórych ograniczeń diagnozowania potrzeb i, ogólnie rzecz ujmując, przyznaje uczestnikom kultury bardziej podmiotowy status i większą autonomię, a co za tym idzie - silniejszą pozycję w relacji z instytucjami. W artykule omówimy szczegółowo oba nurty, analizując ich zakres tematyczny, zaplecze metodologiczne i implikacje dla kształtowania polityki kulturalnej.

1 Pierwszy etap badań, do którego się odwołujemy, zrealizował zespół badaczy Fundacji Obserwatorium Żywej Kultury - Sieci Badawczej i partnerów lokalnych w składzie: Joanna Dziadowiec, Michał Kurcwald, Sławomir Mołda, Kaja Rożdżyńska-Stańczak, Piotr Rynkiewicz, Paweł Tomanek, Aleksandra Zalewska-Królak. Raport z badań można znaleźć pod adresem: http://ozkultura.pl/teksty_ozk.

2 Pełny opis doboru próby można znaleźć w raporcie z pierwszego etapu badań (zob. wyżej). 


\section{DIAGNOZOWANIE POTRZEB}

Postulat badania i uwzględniania potrzeb kulturalnych mieszkańców danego obszaru jest niemal standardowym elementem podręczników i poradników z zakresu diagnozowania kultury lokalnej i planowania jej rozwoju - zarówno w Polsce, jak i za granicą. Co ciekawe, w opracowaniach anglojęzycznych dosyć często przyjmuje się perspektywę „holistyczną”, pisząc o potrzebach całej społeczności lokalnej (community needs) (np. Andersen i Malone 2013: 49, Creative Cities Network 2010: 2, 16; Evans 2001: 128; Mills 2003: 7), podczas gdy w polskiej literaturze przedmiotu rozróżnia się potrzeby jednostkowe i zbiorowe (np. Rutkowski 1982: 40; Szatur-Jaworska 2014: 36-37). Wspólne jest natomiast traktowanie tej kategorii jako w dużej mierze oczywistej i nieproblematycznej - nie w sensie jej z góry znanej zawartości empirycznej (tę mają dopiero ustalić diagnozy), ale jej statusu ontologicznego i epistemologicznego. Jak zauważył już prawie czterdzieści lat temu Stephen Mennell (1979: 236):

[...] decydenci chętnie sięgają po termin ,potrzeba”, ponieważ często uważają, że określanie potrzeb i projektowanie działań mających je zaspokoić, jest prostą sprawą. [...] Nieodparta atrakcyjność tego terminu wynika też z tego, że nazwanie czegoś „potrzebą" pociąga za sobą praktyczny wniosek, że potrzebę tę należy bezwzględnie zaspokoić, podczas gdy w kategorie „pragnień” czy „aspiracji” wpisane jest potencjalne niezaspokojenie (,Pragnienia? Nie można mieć wszystkiego, czego się pragnie").

Można więc przyjąć, że dyskurs ,potrzeb kulturalnych” często ma charakter nie tyle neutralno-opisowy, ile perswazyjny ${ }^{3}$. Użycie tak mocnej kategorii dodaje bowiem wagi dziedzinie traktowanej jako luksusowa, wzbogacająca ludzkie życie, ale daleka od wymogów przetrwania. Kolejny problem związany z „potrzebami kulturalnymi” polega na tym, że w odróżnieniu od dobrze zdefiniowanych potrzeb biologicznych i - w pewnej mierze - psychologicznych nie mają one wyraźnego zakresu empirycznego. Nie chodzi tu nawet o potencjalnie nieskończoną liczbę sposobów ich zaspokajania, ale o stwierdzenie, które z podejmowanych przez ludzi działań zaspokajają tę właśnie, a nie inną potrzebę. (Można to porównać do sytuacji, w której analizując ,potrzebę odżywiania się”, nie bylibyśmy pewni, co możemy uznać za „czynność jedzenia”).

Nieostrość ta powoduje, że „potrzeb kulturalnych” właściwie nie sposób zdefiniować inaczej, niż posługując się definicją nominalną lub projektującą̧. Definicja taka pozostawalaby jednak w sprzeczności z najbardziej rozpowszechnionym sposobem rozumienia potrzeb,

3 Do podobnego wniosku w odniesieniu do rzeczywistości polskich instytucji kultury w latach 80. XX w. doszedł Roman Rutkowski (1982: 66): „Słowo »potrzeby« bywa niejednokrotnie traktowane jako uniwersalny argument mający uzasadnić czynności organizacyjne w sferze działalności kulturalnej. Stanowi ono częstokroć swego rodzaju »alibi« w sytuacjach, w których podejmowane działania kulturalne budzą znaczne wątpliwości co do ich sensu społecznego".

4 Problem ten podobnie ujmuje Mennell (1977: 236), według którego „potrzeby kulturalne to potrzeby poszczególnych ludzi, które można zaspokoić środkami nazywanymi przez nas »kulturowymi«". Łatwo zauważyć, że definicja ta bynajmniej nie rozwiązuje problemu, a jedynie przenosi go poza obręb samego pojęcia potrzeby, podkreślając jednocześnie nominalny charakter „kulturowości”. 
podkreślającym ich nieodzowność i imperatywność. Biologiczne i psychologiczne koncepcje potrzeb skupiają się na ich obiektywnym charakterze, a niewykształcenie u danej jednostki potrzeby charakterystycznej dla jej gatunku (np. ludzkiej potrzeby akceptacji czy przynależności) siłą rzeczy traktuje się w kategoriach patologicznych. Tymczasem w przypadku praktyk kulturalnych i subiektywnego stosunku do kultury inwentarz „potrzeb” (czytaj: preferencji) jest - jak już wspomnieliśmy - potencjalnie nieograniczony, a ich niewystępowanie można ocenić jako stan negatywny i niepożądany tylko na podstawie określonej, silnie normatywnej koncepcji tego, czym jest „kultura”. Stąd ryzyko, że badanie preferencji kulturowych jako „potrzeb" doprowadzi do ich esencjalizacji i postawi w niekorzystnym świetle osoby, które nie odczuwają „,braku” czy „,niedosytu”, ponieważ nie występują u nich „potrzeby kulturalne” w powyższym rozumieniu.

W przeanalizowanych przez nas dokumentach dyskurs ,potrzeb kulturalnych” odgrywa zdecydowanie pierwszoplanową rolę. Jeśli wziąc pod uwagę wyłącznie te spośród nich, których zakres tematyczny ogranicza się do samej diagnozy kultury lub planowania jej rozwoju (a więc wyłączając ogólne strategie rozwoju gminy), to kategoria „potrzeb kulturalnych” pojawia się $\mathrm{w}$ tytule ponad jednej trzeciej z nich (dziesięć $\mathrm{z}$ dwudziestu siedmiu dokumentów). W całej próbie kategoria ta często pojawiała się we fragmentach, w których omawiano najogólniejsze cele stawiane przed instytucjami kulturalnymi. W ponad połowie dokumentów $(54,4 \%)$ jako jeden z tych celów wymieniano „zaspokojenie potrzeb kulturalnych”, a w jednej trzeciej $(33,3 \%)$ - „rozpoznawanie potrzeb kulturalnych” (dla porównania: „Zwiększenie uczestnictwa w kulturze" wymieniono jako cel w 43,9\% dokumentów, ,świadczenie usług kulturalnych" - w 36,8\%, a „pomoc w rozwijaniu zainteresowań” - w 24,6\%).

Analiza ogólnych formuł, za pomocą których definiuje się cele czy misję instytucji, nie mówi nam jednak wiele na temat tego, co dokładnie rozumie się przez ,potrzeby kulturalne”. Przy bliższym spojrzeniu okazuje się, że jest to kategoria używana w sposób dosyć swobodny i nie zawsze konsekwentny, nawet $\mathrm{w}$ obrębie tych samych dokumentów. W żadnym z nich nie znaleźliśmy definicji potrzeb kulturalnych ani odwołania do jakiejkolwiek literatury przedmiotu (socjologicznej ani nawet psychologicznej, dotyczącej ogólnej koncepcji „potrzeb"). Autorzy dokumentów diagnostycznych zakładali więc milcząco, że jest to pojęcie samozrozumiałe, niewymagające komentarza, lub po prostu powielali dominujący dyskurs, nie wnikając w jego znaczenie. Trudno zatem zrekonstruować ich sposób rozumienia „potrzeb kulturalnych", można natomiast przyjrzeć się sposobom operacjonalizacji tego pojęcia, a więc temu, co dokładnie diagnozowano w dokumentach opatrzonych nagłówkiem „badanie potrzeb kulturalnych".

Już pobieżna analiza pokazuje, że kategorię potrzeb traktowano jako termin „,parasolowy”, obejmujący różne aspekty „,stosunku uczestników do kultury”. Pod hasłem „,badania potrzeb” pytano więc respondentów lub uczestników spotkań (zob. dalej) o ich stopień zadowolenia $\mathrm{z}$ aktualnej oferty kulturalnej w gminie lub oferty konkretnych instytucji, o ocenę stanu infrastruktury kulturalnej, jakości kadry instytucji, skuteczności polityki informacyjnej i promocyjnej. Pytaniom o ocenę stanu aktualnego często towarzyszyły prośby o sformułowanie oczekiwań odnośnie do przyszłych kierunków i form działalności kulturalnej - wybranie lub samodzielne zaproponowanie typów aktywności organizowanych przez instytucje, w których 
badani chcieliby brać udział lub które uważają za korzystne dla całej społeczności. Dużo rzadziej pytania „o potrzeby”, a właściwie o preferencje kulturalne, formułowano w sposób, który nie zakładał udziału instytucji w ich zaspokajaniu („Jak najchętniej spędza Pan/Pani wolny czas?”; „Czym najchętniej zajmował(a)byś się w wolnym czasie?”)".

Taki sposób operacjonalizacji ,,potrzeb kulturalnych” nasuwa dwa wnioski. Po pierwsze, pod hasłem „,badania potrzeb” najczęściej próbowano zdiagnozować obszary „,zadowolenia” lub „niedosytu” uczestników związanego z różnymi aspektami ich bieżącej aktywności kulturalnej. Odpowiada to rozumieniu potrzeby jako poczucia braku, które domaga się jakiegoś rodzaju działania mającego jak najszybciej usunąć to poczucie (krótko mówiąc - zaspokoić potrzebę), nie zaś koncepcji potrzeb związanych z samorealizacją, których zaspokojenie jest długotrwałym i skomplikowanym procesem (zob. Maslow 2009: 116-117). Po drugie, w analizowanych dokumentach jako źródło braku i podmiot odpowiedzialny za jego usunięcie wskazuje się instytucje kultury. W tej wizji „niezaspokojenie kulturalne” uczestników jest spowodowane przede wszystkim niedostateczną lub „niedostosowaną do potrzeb” ofertą lokalną, a w dalszej kolejności - brakami infrastruktury i innymi aspektami działalności instytucji. Przyjmuje się tu milcząco lub jawnie, że ujawnione braki instytucji powinny zostać zniwelowane przez same instytucje, nie dopuszcza się natomiast możliwości, że uczestnicy kultury mogą we własnym zakresie „zrekompensować sobie” niską jakość kultury instytucjonalnej - a jeśli tak, to traktuje się taką sytuację jako wysoce niepożądaną. „Prywatyzację” kultury, ,zamykanie się w domu” i podejmowanie aktywności kulturalnych w wąskim gronie rodziny lub znajomych w dużej części dokumentów oceniono zdecydowanie negatywnie, widząc w niej świadectwo porażki instytucji. W kilku przypadkach stwierdzono wręcz, że takie formy aktywności świadczą o „mało rozwiniętych potrzebach kulturalnych”, co raz jeszcze potwierdza, że ujmowanie preferencji kulturalnych przez pryzmat potrzeb może iść w parze z ich silną normatywizacją.

Do interesujących wniosków doprowadziła nas też analiza tego, w jaki sposób diagnozowano określone rodzaje „potrzeb” (a więc - rozwińmy ponownie tę kategorię - ocen, preferencji i oczekiwań). Lista metod badawczych stosowanych w dokumentach diagnostycznych była dosyć krótka ${ }^{6}$, a „potrzeby” stwierdzano niemal wyłącznie za pomocą badań ankietowych i wywiadów fokusowych lub różnego rodzaju spotkań konsultacyjnych ${ }^{7}$. Ponieważ - jak już pisaliśmy - sama kategoria „potrzeb” nie miała w dokumentach jednolitego zakresu empirycznego, do szczegółowej analizy wybraliśmy oczekiwania formułowane przez uczestników

\footnotetext{
5 Według Rutkowskiego (1982: 66) podobnie operacjonalizowano kategorię potrzeb kulturalnych w praktyce diagnostycznej w latach 80 . XX w.: „Nieporozumienia wynikają przede wszystkim z utożsamiania potrzeb z domniemanymi oczekiwaniami, przejściowymi modami czy też, w najlepszym razie, z deklarowanymi zainteresowaniami jednostek".

6 Omówienie metod stosowanych w diagnozach, zob. raport z pierwszego etapu badania: http://ozkultura.pl/ teksty_ozk.

7 Na podstawie fragmentów diagnoz opisujących użyte techniki badawcze nie zawsze można było stwierdzić, czy badanie polegające na konsultacji z grupą wybranych osób - najczęściej nazywane „,warsztatami diagnostycznymi” lub „warsztatami strategicznymi” - spełniało kryteria wywiadu fokusowego, a więc czy zostało przeprowadzone według przygotowanego scenariusza i pod kierunkiem wyszkolonego moderatora. Dlatego w niniejszym artykule potraktowaliśmy wszystkie tego typu badania łącznie.
} 
badań wobec instytucji kulturalnych. Za takim wyborem przemawiało przede wszystkim to, że oczekiwania można - przynajmniej teoretycznie - badać w sposób bardziej jakościowy i otwarty niż oceny, które łatwiej sprowadzić do postaci skali. Częstość diagnozowania różnych rodzajów oczekiwań przy użyciu poszczególnych metod przedstawia rysunek 1 .

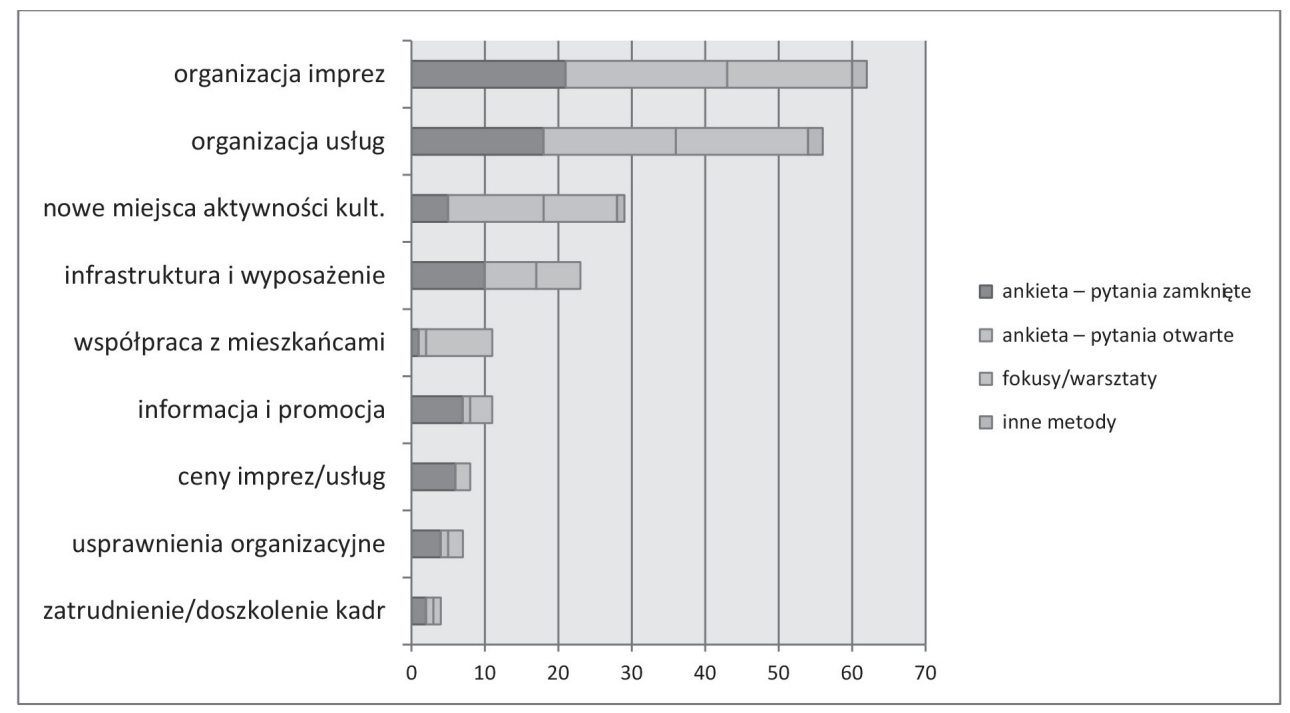

Rysunek 1. Metody diagnozowania poszczególnych rodzajów oczekiwań badanych (liczba wystąpień w próbie)

Uwaga: liczba wystąpień może przekraczać liczbę dokumentów w próbie, ponieważ jeden rodzaj oczekiwania mógł pojawić się w dokumencie kilkukrotnie i zostać zdiagnozowany przy użyciu kilku technik

Źródło: Paweł Tomanek, opracowanie własne

Stwierdzone w dokumentach oczekiwania uczestników kultury można podzielić na trzy ogólne kategorie. Pierwsza, najczęściej występująca w dokumentach, to oczekiwania dotyczące oferty kulturalnej, a więc te najbliższe kategorii „potrzeb kulturalnych” w omówionym wcześniej rozumieniu. Tego typu oczekiwania najczęściej diagnozowano za pomocą badań ankietowych - kwestionariuszy, w których można było wybrać pożądany typ imprez lub usług kulturalnych ${ }^{8}$ z przedstawionej kafeterii, lub otwartych pytań o to, jakich imprez lub usług badanym „,brakuje w gminie” lub „w jakich formach aktywności chcieliby brać udział”. Drugi rodzaj oczekiwań dotyczył „twardych” aspektów działalności instytucji, a więc ich infrastruktury i wyposażenia czy samego istnienia placówek kulturalnych. Tego rodzaju oczekiwania również stwierdzano głównie za pomocą badań ankietowych, ale - co

8 Przez „usługi kulturalne” rozumieliśmy w badaniu wszelkie stałe formy działalności kulturalnej, a więc zajęcia w domach kultury, udostępnianie książek, prasy i internetu w bibliotekach itp. W przypadku bardziej cyklicznych form działalności za „stałe” uznaliśmy te, które organizowano co najmniej raz w miesiącu (np. spotkania dyskusyjnych klubów filmowych). 
interesujące - oczekiwanie stworzenia nowych miejsc aktywności kulturalnej pojawiało się wyraźnie częściej w odpowiedziach na pytania otwarte, co łatwo wytłumaczyć ostrożnością autorów i zleceniodawców ankiet (możliwość powstania takich miejsc - z reguły wiążąca się z dużymi kosztami - nie wszędzie jest realna, a jej zasugerowanie w pytaniu zamkniętym brzmi już niemal jak obietnica lub zobowiązanie polityczne). Trzecia, najliczniejsza, ale najrzadziej reprezentowana grupa oczekiwań dotyczy organizacyjnych aspektów działania instytucji. Przy zaledwie kilkukrotnych wystąpieniach trudno pokusić się o zdecydowane wnioski dotyczące rozkładu metod diagnostycznych, ale uwagę zwraca fakt, że wzmianki o oczekiwaniu pogłębionej współpracy z mieszkańcami pojawiały się niemal wyłącznie w omówieniach wyników badań fokusowych lub warsztatów. Oznacza to, że tego aspektu nie uwzględniano w zamkniętych kwestionariuszach, nie nasuwał się on też respondentom odpowiadającym na ogólne pytania otwarte o to, co należałoby zmienić w funkcjonowaniu instytucji (takie pytanie pojawiło się tylko w dwóch kwestionariuszach). Badania fokusowe i warsztaty z jakiegoś powodu - być może składu uczestników, być może mniej ustrukturyzowanej formy - okazały się metodą bardziej sprzyjającą wyrażaniu tego rodzaju oczekiwań.

Jest to ważna wskazówka dla organizatorów badań diagnostycznych, którzy, polegając wyłącznie na badaniach ankietowych, mogą niezamierzenie spowodować, że pewne rodzaje mniej oczywistych „potrzeb” uczestników znajdą się poza zakresem badania. Co więcej, tego rodzaju diagnozowanie ,potrzeb” opiera się na założeniu, że badani są ich w pełni świadomi lub przynajmniej potrafią je sobie uświadomić, jeśli się ich do tego skłoni odpowiednimi pytaniami. Mennell (1977) nazywa taką koncepcję potrzeb kulturalnych ,jednowymiarową", ponieważ nie dopuszcza ona sytuacji, w której uczestnicy kultury mogą mieć potrzeby „potencjalne” czy „ukryte”, ujawniające się dopiero w momencie kontaktu z nowymi doświadczeniami kulturowymi. Innymi słowy, badani mogą trafnie przedstawić swoją aktualną hierarchię preferencji, ale nie potrafią przewidzieć, jakie miejsce zajęłyby w niej formy aktywności, których jeszcze nie znają (1977: 243). Oprócz tego w badaniach ankietowych pytaniom o to, w jakich rodzajach aktywności badani „chętnie wzięliby udział”, najczęściej nie towarzyszą żadne informacje dotyczące ich przewidywanych kosztów (finansowych, czasowych i innych). Prowadzi to do sytuacji, w której badanym oferuje się „darmowe dobra”, przez co „często zgadzają się [oni] na olbrzymią liczbę podsuwanych propozycji, ale kiedy proponowane aktywności stają się rzeczywiście dostępne, nie korzystają z nich" (Mennell 1977: 244).

Według Mennella (1977: 244) ograniczenia ,jednowymiarowej” koncepcji potrzeb można zniwelować, przechodząc od badania odizolowanych jednostek (jak to ma najczęściej miejsce w badaniach ankietowych) do badania rzeczywistych grup i sieci społecznych. Pozwala to zrekonstruować dynamikę życia kulturalnego w danej społeczności i wskazać miejsca lub osoby stwarzające nadzieję na jego rozwój lub zmianę. Wymagałoby to jednak całkowitej zmiany metodologii i położenia silniejszego nacisku na metody jakościowe, takie jak wywiady indywidualne i grupowe lub obserwacja etnograficzna. Konieczne byłoby też przynajmniej częściowe przeformułowanie ramy teoretycznej badań, polegające na uzupełnieniu perspektywy potrzeb o rachunek zasobów, dzięki którym jednostki i grupy mogą podejmować działania kulturalne i wpływać na aktywność innych ludzi. 


\section{DIAGNOZOWANIE ZASOBÓW UCZESTNIKÓW}

Przez zasoby uczestników kultury rozumiemy wszelkiego rodzaju cechy i formy kapitału sprzyjające (przynajmniej potencjalnie) ich aktywności kulturalnej9. W odróżnieniu od „potrzeb" samo pojęcie zasobów w zaproponowanym rozumieniu bardzo rzadko pojawiało się w dokumentach - jest to skonstruowana przez nas kategoria analityczna ${ }^{10}$. Wyraźnie częściej pisano o ,potencjałach” poszczególnych osób i grup, przede wszystkim młodzieży, seniorów lub mieszkańców gminy ogółem ${ }^{11}$. Postanowiliśmy jednak nie przyjmować tego terminu za główną kategorię analityczną ze względu na znaczenie „,potencjalności” jako „niezrealizowania", które niepotrzebnie zawęziłoby pole analizy.

Ponieważ zasoby - podobnie jak ,potrzeby” - okazały się kategorią bardzo zróżnicowaną wewnętrznie, uporządkowaliśmy tę różnorodność według dwóch kryteriów, wyprowadzonych z analizy dokumentów. Pierwsze dotyczy poziomu, na którym występują zasoby (według autorów diagnoz); wyróżniliśmy tu zasoby indywidualne, międzyludzkie i wspólnotowe. Drugie dotyczy stopnia wykorzystania zasobów; przyjęliśmy tu typologiczne rozróżnienie zasobów wykorzystywanych, nieupublicznionych i blokowanych. Następne akapity poświęcimy szczegółowemu omówieniu tych rozróżnień.

Zasoby indywidualne. Ta kategoria zasobów obejmuje wszystkie „kulturotwórcze” cechy jednostek i formy posiadanego przez nie kapitału (z wyjątkiem kapitału społecznego - zob. dalej). Istnienie zasobów tego rodzaju stwierdzano dosyć rzadko - najczęściej, w 15,8\% dokumentów, pojawiły się wzmianki o rozwiniętych potrzebach kulturalnych mieszkańców lub ich poszczególnych grup. Nieco rzadziej (14,0\% dokumentów) wspominano o pasjach i zainteresowaniach uczestników kultury, zarówno w kontekście amatorskiej twórczości artystycznej, jak i różnego rodzaju zainteresowań realizowanych grupowo (grupy rekonstrukcyjne, grupy gier fabularnych itp.). Kolejne trzy kategorie - duża ilość wolnego czasu (14,0\%), umiejętność korzystania z nowych mediów (14,0\%) oraz duża wiedza i umiejętności (7,0\%) - pojawiały się niemal wyłącznie w odniesieniu do dwóch grup „szczególnej troski”

9 W wielu dokumentach oprócz zasobów diagnozowano również różnego rodzaju ograniczenia uczestników kultury, ale ze względu na brak miejsca nie jesteśmy tu w stanie przeanalizować relacji między tymi dwiema kategoriami.

10 W dokumentach dosyć często wymieniano zasoby innego rodzaju - ,materialne”, ,naturalne” lub ,przyrodnicze” (głównie w kontekście turystyki) lub zasoby przypisywane instytucjom - ,infrastrukturalne”, ,finansowe” „biblioteczne”, „,cyfrowe”. Kilkukrotnie wspomniano o „zasobach ludzkich” lub „,zasobach osobowych”. W sześciu dokumentach użyto terminu „,zasoby dziedzictwa kulturowego” (w kontekście zabytków i innych obiektów kultury materialnej). Jednokrotnie wystąpiły wyrażenia: „zasoby intelektualne i emocjonalne”, „twórcze zasoby miasta” i ,zasoby kapitału kulturowego".

11 Oto kilkanaście wybranych wyrażeń obrazujących ten sposób używania terminu „potencjał”: „wewnętrzny potencjał tkwiący w każdej jednostce”, ,,potencjał kulturowy wybranych grup ludzkich”, ,potencjał intelektualny i artystyczny tkwiący w mieszkańcach”, ,potencjał mieszkańców (ich talenty, pomysły, zdolności)”, „drzemiące potencjały społeczności lokalnych”, „,kulturotwórczy potencjał mieszkańców dzielnicy”, ,potencjał środowisk artystycznych”, ,,potencjał, jakim dysponują młodzi ludzie”, ,,potencjał uzdolnionej i utalentowanej młodzieży”, ,potencjał seniorów/osób starszych” (kilkukrotnie), ,potencjał, jaki [seniorzy] mogą przekazać jako współtwórcy i uczestnicy kultury”, ,„potencjał ze względu na zapał, pomysły, wolny czas i doświadczenie życiowe”, ,potencjał do tworzenia własnych oddolnych inicjatyw”. 
będących najczęściej wymienianymi adresatami działań kulturalnych: młodzieży i osób starszych $^{12}$. Uderzające jest natomiast to, że tylko sporadycznie stwierdzano wysoka zamożność uczestników kultury $(5,3 \%)$ lub ich wysokie wykształcenie $(1,8 \%)$, a więc klasowe czynniki wpływające na aktywność kulturalną. Można by z tego wnioskować, że wizerunek uczestników wyłaniający się ze zbadanych dokumentów jest w dużej mierze „odklasowiony”, ale przeczą temu w pewnym stopniu wyniki równoległej analizy ograniczeń uczestników (niemal w jednej czwartej dokumentów jako czynnik utrudniający im aktywność kulturalną wymieniono niską zamożność).

Zasoby międzyludzkie. Do tej kategorii zaliczyliśmy wszelkie odniesienia do jakości więzi w społeczności lokalnej i łatwości mobilizacji jej członków. Wysoki poziom zaangażowania społecznego okazał się najczęściej diagnozowanym zasobem w ogóle (26,3\% dokumentów). Wskazywano tu przede wszystkim siłę i zakres oddziaływania lokalnych organizacji pozarządowych, zaangażowanie mieszkańców w wolontariat i okazjonalną pomoc przy różnego rodzaju wydarzeniach i projektach. Rzadziej wspominano o sile sieci społecznych $(14,0 \%)$ i silnych lokalnych liderach (12,3\%). W tym pierwszym przypadku chodziło o nieformalne sieci kontaktów umożliwiające wymianę informacji oraz wspólne realizowanie różnego rodzaju pasji, natomiast w tym drugim - o konkretne osoby stanowiące ,zworniki” społeczności lokalnej, motywujące innych i koordynujące wspólne działania.

Zasoby wspólnotowe. W tej kategorii umieściliśmy cechy kulturowe charakteryzujące wspólnotę lokalną jako całość. Chodziło tu przede wszystkim o silną tradycję i tożsamość lokalną (24,6\% dokumentów), które miałyby stanowić podstawę dla rozmaitych działań kulturalnych. Co ciekawe, zasób ten - w odróżnieniu od wszystkich wcześniej wymienionych według autorów dokumentów mógł być wykorzystywany zarówno w działaniach kulturalnych skierowanych do mieszkańców, jak i tych obliczonych na udział turystów. W tym pierwszym wypadku tradycję i tożsamość opisywano jako spoiwo społeczności lokalnej (a więc zasób przekładający się na zasoby międzyludzkie), natomiast w tym drugim traktowano go jako potencjalny albo już wykorzystywany wabik na turystów. Jedynie w 7,0\% dokumentów jako jeden z zasobów gminy wymieniono jej wielokulturowość, co nie dziwi w świetle stosunkowo homogenicznego składu populacji w Polsce. Również w tym przypadku wartość zasobu opisywano dwojako - jako czynnik przeobrażający mieszkańców (,wzmocnienie tolerancyjności i otwarcie na mniejszości etniczne”) lub jako element atrakcyjności turystycznej (,wizerunek regionu”, ,„promocja regionu”).

Do wymienionych kategorii zasobów można przyłożyć kryterium stopnia ich wykorzystywania (według autorów dokumentów lub cytowanych przez nich osób). Ponieważ stopień ten nie zawsze stwierdzano wprost, a często nie dało się go również określić na podstawie kontekstu, próba kategoryzacji wszystkich przypadków i przeprowadzenia analizy ilościowej mijałaby się z celem. Dlatego zamiast klasyfikacji zaproponujemy typologię trzech „stanów”,

12 Pełniejsze omówienie charakterystyk tych dwóch grup w dokumentach diagnostycznych, zob. raport z pierwszego etapu badania: http://ozkultura.pl/teksty_ozk. 
jakie przypisywano zasobom - zasobów wykorzystywanych, nieupublicznianych i blokowanych. Skupimy się na jakościowej analizie wybranych przypadków, a zwłaszcza tego, jakie rodzaje zasobów wiązano z poszczególnymi „stanami” i jakie wskazywano przyczyny takiego stanu rzeczy. Pominiemy przy tym zasoby wspólnotowe, ponieważ refleksja nad stopniem i czynnikami ich wykorzystania pojawiała się dużo rzadziej.

Zasoby wykorzystywane. „Wykorzystanie” zasobów oznacza, że przekładają się one na jakiegoś rodzaju aktywność kulturalną i że procesu tego nie blokują żadne wewnętrzne ani zewnętrzne czynniki (zob. dalej). Nie musi to oznaczać „pełnego” czy „optymalnego” wykorzystania - trudno zresztą powiedzieć, w jaki sposób można by to zmierzyć. Dodatkową trudność stwarza to, że „wykorzystanie” można różnie szacować w zależności od tego, czy jego zakres ma dotyczyć tylko prywatnych lub towarzyskich form aktywności kulturalnej, czy też działań w sferze publicznej, angażujących szersze grono osób. Jak już wspomnieliśmy, samodzielne formy aktywności kulturalnej podejmowane bez pośrednictwa instytucji w niektórych dokumentach wartościowano zdecydowanie negatywnie, w innych zaś - o czym jeszcze napiszemy - przyjmowano, że są one zaledwie „zalążkiem” prawdziwej aktywności.

Zasoby indywidualne bardzo rzadko oceniano jako wykorzystywane - widziano w nich raczej pole do intensywniejszego zagospodarowania (zob. dalej). Wyjątkiem jest tu właściwie tylko umiejętność korzystania z nowych mediów, którą kilkukrotnie przedstawiono jako klucz do zdobywania informacji o życiu kulturalnym w gminie. Dużo częściej za wykorzystywane uznawano zasoby z poziomu międzyludzkiego, związane z siłą sieci społecznych i stopniem zaangażowania $\mathrm{w}$ życie wspólnoty. Ten ostatni zasób $\mathrm{w}$ wielu dokumentach przedstawiano jako najbardziej pożądany (lub wskazywano jego deficyt jako główny czynnik hamujący życie kulturalne w gminie). „Oddolność” życia kulturalnego przybierała w opisach dwie formy samoorganizacji mieszkańców, podejmujących działania bez pośrednictwa instytucji, lub ich udziału w działaniach instytucjonalnych jako pomysłodawców czy współwykonawców:

Druga kwestia to obecność pośród 31 podmiotów wskazanych podczas warsztatu, jako prowadzące działalność kulturalną, aż 24 osób fizycznych. Taka duża reprezentacja pojedynczych aktywistów i twórców, wraz z pozarządowym, społecznym charakterem większości podmiotów instytucjonalnych oddaje bardzo obywatelski, oddolny charakter działalności kulturalnej w mieście.

[Łaskarzew, gmina małomiejska, diagnoza kultury w miejscowości] ${ }^{13}$

Ponadto ważnym ogniwem działalności NOK jest współpraca, na zasadzie realizowania pomysłów, promowania działalności, organizowania i współorganizowania imprez, z lokalnymi patriotami, działaczami, aktywistami oraz ludźmi ,z pomysłem na siebie i lokalną przestrzeń”.

[Nadarzyn, gmina małomiejska, diagnoza miejskiego ośrodka kultury]

Siłę nieformalnych sieci społecznych niemal zawsze przedstawiano w pozytywnym świetle, jednak w niektórych kontekstach aktywność tych sieci uznawano za świadectwo

13 Jednym z kryteriów konstrukcyjnych próby była wielkość ośrodka gminnego, dlatego nasze kategorie tylko częściowo pokrywają się z klasyfikacją gmin miejskich, miejsko-wiejskich i wiejskich. Wyróżniliśmy miasta na prawach powiatu, gminy miast powiatowych (gminy miejskie z siedzibą w mieście powiatowym), gminy małomiejskie (gminy miejskie lub miejsko-wiejskie z siedzibą w mieście innym niż powiatowe) i gminy wiejskie. 
pewnego niedomagania instytucji. Dotyczy to na przykład sfery informacji o działaniach kulturalnych. W diagnozach często podkreślano konieczność usprawnienia polityki informacyjnej instytucji - na przykład szerszego korzystania z nowych mediów - aby wiadomości o ich ofercie docierały do większej liczby potencjalnych uczestników. To, że mieszkańcy częściej dowiadywali się o wydarzeniach kulturalnych nieformalnymi kanałami, od znajomych, uznawano czasem za sytuację nie tyle niepożądaną (w końcu każdy kanał jest dobry, jeśli tylko przysparza uczestników), ile ,zastępczą”:

Informacje o wydarzeniach i działaniach podmiotów tworzących oficjalny obieg kultury, zdaniem informatorów są rozproszone i nie wiadomo gdzie ich szukać. Poszczególne grupy wolą wykorzystywać prywatne kontakty do przekazywania informacji.

[Łaskarzew, gmina małomiejska, diagnoza kultury w gminie]

W innych dokumentach akceptowano taki stan rzeczy jako naturalny:

Głównym i zdecydowanie dominującym źródłem wiedzy o wydarzeniach kulturalnych jest dla naszych respondentów Internet. Korzysta z niego w tym celu aż $99 \%$ badanych osób (z portali społecznościowych - 84\%). [...] Widać więc, że mieszkańcy Ełku, korzystając z mediów elektronicznych, niejako samodzielnie przekazują sobie informacje o ciekawych wydarzeniach w mieście. [Ełk, gmina miasta powiatowego, diagnoza kultury w gminie]

Zasoby nieupubliczniane. W niektórych przypadkach zasoby diagnozowane u uczestników kultury uznawano za wykorzystywane w niewielkim stopniu lub na zbyt małą skalę. W skrajnym przypadku oznaczało to, że przybierały postać „uśpioną”, czyli istniały wyłącznie potencjalnie, nie przekładając się na żadne formy aktywności kulturalnej. Częściej jednak autorzy diagnoz odnosili się do sytuacji, w której uczestnicy kultury wykorzystywali swoje zasoby w działaniach ograniczonych do sfery prywatnej lub towarzyskiej, bez zamiaru ich rozwinięcia czy upublicznienia. Jak już wspomnieliśmy, takie ograniczone wykorzystywanie zasobów dosyć często uznawano za swego rodzaju marnotrawstwo, a w rekomendacjach diagnoz zalecano, aby pracownicy instytucji kulturalnych odpowiednimi działaniami zachęcali mieszkańców do podzielenia się z innymi swoją wiedzą, talentem, umiejętnościami czy dokonaniami.

Jako podstawowy zasób indywidualny, który uczestnicy wykorzystują ,prywatnie” i który mogliby wykorzystać z większym pożytkiem dla siebie i innych, wskazywano pozostający do ich dyspozycji czas wolny. Najczęściej wymieniano w tym kontekście dwie grupy mieszkańców - młodzież i osoby starsze:

Młodzież dysponuje największą ilością wolnego czasu do wykorzystania. Znajduje się najbliżej życia lokalnego, ma więc największą szansę, aby aktywnie w nim uczestniczyć. Nastolatki, które zamieszkują sąsiednie wsie, dysponują wolnym czasem najczęściej bezpośrednio po zajęciach w szkole. Dla nich Orneta, miasto, w którym się uczą, może stanowić atrakcyjne miejsce spotkań. [Orneta, gmina małomiejska, diagnoza kulturalna gminy]

Także osoby starsze, mające często większe możliwości poświęcenia bezinteresownie swojego czasu, mogą czerpać niewątpliwe korzyści pozamaterialne z działalności, pozwalającej aktywnie uczestniczyć w kreowaniu życia kulturalnego swojego miejsca zamieszkania.

[Podkowa Leśna, gmina małomiejska, diagnoza kulturalna gminy] 
W jednym z przypadków szansy na przeciągnięcie uczestników ze sfery prywatnej i towarzyskiej do publicznej upatrywano też w umiejętności posługiwania się nowymi mediami. Chodziłoby o rozwinięcie działań podejmowanych na co dzień przez użytkowników internetu (w tym przypadku młodzież gimnazjalną) do postaci ,pełnowymiarowej” działalności kulturalnej:

Wiele z działań gimnazjalistów sytuuje się w obrębie stref nieznanych dorosłym. Wykorzystują oni nowe media, techniki, zasoby kultury. Te treści można wykorzystywać i budować na nich działania edukacyjne czy kulturalne. Można budować wirtualne Babice w Second Life i prowadzić tam dyskusje bądź zaprojektować idealny dom kultury. Można nakręcić film o wikliniarstwie telefonami komórkowymi, można stworzyć prostą grę komputerową z wykorzystaniem zamku Lipowiec.

[Babice, gmina wiejska, badanie potrzeb kulturalnych młodzież gimnazjalnej]

Największe nadzieje na rozwój działalności kulturalnej pokładano jednak w sile relacji międzyludzkich i chęci mieszkańców do angażowania się we wspólne przedsięwzięcia (niekoniecznie kulturalne). Wzmianki o tego rodzaju kapitale społecznym bywały bardzo ogólne - dosyć często nie precyzowano grup, których więzi i zaangażowanie miałyby zostać wykorzystane, lub nie określano, jakie działania lub typy działań miałyby to umożliwić. W niektórych diagnozach podejmowano jednak refleksję nad tym, jak przeprowadzić „upublicznienie" działań kulturalnych podejmowanych na mniejszą skalę przez samych uczestników, nie doprowadzając przy tym do utraty ich spontanicznego i oddolnego charakteru. Sugerowano tu przede wszystkim wstrzemięźliwość instytucji - przyjęcie przez nie roli pomocnika lub co najwyżej koordynatora zamiast „narzucania się” uczestnikom z własnymi schematami działania:

Należy podkreślić, że opisane przez nas grupy stanowią ważny dla Łaskarzewa kapitał kulturowy, z zasobów, którego miasto (i mieszkańcy) mogą i powinni czerpać. Nie znaczy to, by w sposób bezrefleksyjny starać się włączyć ww. grupy w obszar dominującego obiegu kultury, lecz wykorzystać ich potencjał i starać się - w sposób nieinwazyjny dla nich - włączać w szersze działania. Oddolna aktywność mieszkańców to jeden z największych potencjałów miasta. Pytanie, na którym koncentrować się powinna dyskusja, to kształt polityki wspierania właśnie tych, kluczowych dla kultury i pomyślności całego miasta podmiotów kultury.

[Łaskarzew, gmina małomiejska, diagnoza kulturalna miejscowości]

[Gimnazjaliści] to środowisko, które samo sobie organizuje atrakcje, rozrywki, zajęcia. Ważne jest, aby te procesy wspomagać (zapewniając zaplecze i pomoc organizacyjną) i kierować w stronę ciekawych, twórczych projektów.

[Babice, gmina wiejska, diagnoza potrzeb kulturalnych młodzieży gimnazjalnej]

Zasoby blokowane. Podobnie jak w przypadku zasobów nieupublicznianych, mamy tu do czynienia z sytuacją, w której pomysły, umiejętności i zaangażowanie uczestników nie mogą się przełożyć na działania w sferze publicznej (lub przekładają się na nie w dużo mniejszym stopniu, niż byłoby to możliwe). Blokowanie zasobów oznacza jednak, że za taki stan rzeczy odpowiedzialne są czynniki zewnętrzne - bariery społeczne i instytucjonalne, które 
zniechęcają potencjalnych współtwórców kultury. W najogólniejszym sensie może chodzić o brak zrozumienia i wsparcia ze strony społeczności lokalnej, co szczególnie mocno podkreślano w przypadku osób starszych i niepełnosprawnych, stawianych przez innych ludzi poza nawiasem aktywności kulturalnej:

Osoby niesamodzielne (zarówno niepełnosprawne, jak i starsze) dysponują dużym potencjałem twórczym, wrodzonym lub wypracowanym systematyczną pracą w ramach terapii zajęciowej w placówkach wsparcia. Nie zawsze mają możliwość jego wyeksponowania lub, co więcej, z powodu swej ułomności boją się dezaprobaty społecznej. Przez ogół społeczeństwa są najczęściej traktowane jako osoby ułomne, niemające nic ciekawego do zaoferowania, mało wnoszące w rozwój kultury i społeczności lokalnej. Takie krzywdzące postrzeganie osób niesamodzielnych powoduje u nich problemy w nawiązaniu kontaktów interpersonalnych, zamknięcie się w sobie, a w konsekwencji izolację społeczną.

[Bartoszyce, gmina miasta powiatowego, lokalny plan rozwoju]

Częściej jednak ,winą” za blokowanie zasobów obarczano same instytucje kulturalne. Ten wątek w kilku diagnozach okazał się bardzo rozbudowany, a marnowanie oddolnego potencjału mieszkańców przez piętrzenie trudności biurokratycznych uznawano za jeden z głównych problemów życia kulturalnego w gminie. W skrajnej postaci relacje między instytucjami a nieformalnymi inicjatywami mieszkańców przedstawiano jako zderzenie dwóch światów, kierujących się odmienną logiką i niepotrafiących się ze sobą porozumieć, co prowadziło do zablokowania pewnych działań jeszcze przed ich podjęciem:

Równocześnie, nasi rozmówcy podkreślali duży potencjał jednostek, który nie może jednak przekształcić się w działania korzystne dla wspólnoty ełczan. Wraz z zasygnalizowanym wyżej problemem słabego usieciowienia idzie w parze „bariera wejścia”, polegająca na trudnościach we współpracy między często niesformalizowanymi grupami, związanymi ze środowiskami artystycznymi, alternatywnymi, niszowymi a przestrzenią instytucji, funkcjonujących w oparciu o sformalizowane reguły działania i podejmowania decyzji.

[Ełk, gmina miasta powiatowego, diagnoza kulturalna gminy].

Skutkiem nieoptymalności w realizacji usług kulturalnych w gminie jest przede wszystkim brak aktywnego udziału mieszkańców w życiu kulturalnym. [...] Co więcej, potencjał mieszkańców (ich talenty, pomysły, zdolności) nie jest wykorzystywany do rozwoju kultury. [...] ten stan rzeczy wynika również z uznanego za główny problem faktu, iż usługi realizowane są bez udziału mieszkańców i niezgodnie z ich oczekiwaniami, co zniechęca osoby mieszkające w gminie do komunikacji z instytucjami.

[Konstancin-Jeziora, gmina małomiejska, diagnoza kulturalna gminy].

Blokowanie zasobów mogło też nastąpić na późniejszym etapie działalności kulturalnej. W jednym z dokumentów wspomniano o lokalnych liderach, którzy samodzielnie - to znaczy bez wsparcia instytucji - organizowali działania kulturalne, ale po jakimś czasie ich zapał się wyczerpywał, zniechęcali się lub po prostu zaczynali poświęcać więcej czasu swoim prywatnym sprawom, a w skrajnym przypadku wyjeżdżali, pozbawiając społeczność swoich zasobów. 
Również w takich sytuacjach winą obciążano instytucje, które nie potrafiły w porę dostrzec potencjału tych inicjatyw i zaangażować się w ich podtrzymywanie i rozwój:

Wydaje się, że wyraźnie widoczne jest w Łaskarzewie rozbudzenie wielu oczekiwań, jednak ze względu na nietrwałość inicjatyw podyktowanych koniecznością utrzymywania motywacji lidera na wysokim poziomie, pozostają one niespełnione. Źródłem takiego stanu jest słabość instytucji mogących wspierać inicjatywy mieszkańców.

[Łaskarzew, gmina małomiejska, diagnoza kulturalna miejscowości]

Inaczej niż w przypadku potrzeb, zasoby uczestników nie zawsze diagnozowano za pomocą wyraźnie określonych metod, a przynajmniej nie zawsze się na te metody powoływano. Często zasoby określano „z zewnątrz” - autorzy diagnoz samodzielnie charakteryzowali mieszkańców gminy lub ich poszczególne grupy, uznając zapewne, że wystarczy do tego wiedza płynąca ze „znajomości” badanego obszaru (część autorów była urzędnikami gminnymi lub pracownikami lokalnych instytucji kultury). Tego rodzaju charakterystyki często znajdowaliśmy w analizach SWOT, które niekiedy stanowiły zwieńczenie bardziej rozbudowanego procesu diagnostycznego, ale we wspomnianych przypadkach po prostu go zastępowały. Kiedy indziej diagnoza zasobów opierała się na bezpośrednim kontakcie z uczestnikami kultury, najczęściej przybierającym postać badań fokusowych lub różnego rodzaju spotkań konsultacyjnych (zob. wyżej).

Najbardziej rozbudowane rachunki zasobów znaleźliśmy w diagnozach opartych w dużej mierze na badaniach obserwacyjnych i etnograficznych. Takich diagnoz znalazło się w próbie zaledwie pięć, co znamienne - przeprowadzono je w gminach małomiejskich i jednej gminie wiejskiej. Być może w większych miejscowościach przyjmuje się, że badania etnograficzne są zbyt ,punktowe”, aby móc dostarczyć wyczerpujących informacji na temat lokalnego życia kulturalnego. Nie zmienia to faktu, że badania tego rodzaju w największym stopniu dają szansę na zaobserwowanie kultury w działaniu, odchodząc od jej statycznego ujęcia implikowanego przez badanie potrzeb. Rodzajem zasobów najsilniej związanym z badaniami obserwacyjnymi i etnograficznymi (to znaczy wychwytywanym przez nie relatywnie częściej niż przez inne zastosowane metody) okazały się wszelkie formy samoorganizacji uczestników kultury, czyli wspólne aktywności kulturalne podejmowane przez nich poza obiegiem instytucjonalnym.

\section{PODSUMOWANIE}

Nurty diagnozowania ,ppotrzeb kulturalnych” i zasobów uczestników kultury nie wykluczają się wzajemnie i w wielu dokumentach występują obok siebie, choć najczęściej z większą lub mniejszą przewagą tego pierwszego. Nie można więc stwierdzić, że mamy tu do czynienia z dwoma całkowicie odrębnymi „sposobami myślenia o kulturze”, przynajmniej w sensie empirycznym. Nie zmienia to jednak faktu, że perspektywy potrzeb i zasobów opierają się na częściowo odmiennych założeniach i mają odmienne implikacje dla planowania działalności kulturalnej. Perspektywa potrzeb kulturalnych, zoperacjonalizowana do ,jednowymiarowej” postaci gustów i oczekiwań, wpisuje się w dosyć statyczne ujęcie aktywności kulturalnej, na gruncie którego można właściwie tylko reprodukować swoją aktualną hierarchię preferencji. Prowadzi też do indywidualistycznego, atomistycznego modelu badania kultury, ponieważ 
potrzeby przypisuje się jednostkom i pod tym kątem dobiera się metody badawcze, najczęściej poprzestając na badaniach ankietowych. Wreszcie powiązanie potrzeb kulturalnych z instytucjonalnym obiegiem kultury - jako domyślnym, pożądanym i „prawomocnym” obszarem ich zaspokajania - przekłada się na wizję uczestników kultury jako w dużej mierze biernych, „oczekujących” na ofertę instytucji i niezdolnych do samodzielnego podążania za swoimi pomysłami i aspiracjami.

Na tym tle perspektywa zasobów może się wydawać stosunkowo ,postępowa”, ponieważ przyznaje ona uczestnikom kultury bardziej podmiotowy status i większe możliwości samodzielnego działania. Z dostarczycieli informacji o własnych potrzebach, z których dopiero instytucje kultury będą potrafiły zrobić właściwy użytek, uczestnicy stają się w tej optyce rzeczywistymi lub potencjalnymi współtwórcami lokalnego życia kulturalnego. Przestają też być w dużej mierze ujmowani jako odizolowane jednostki, ponieważ do najważniejszych diagnozowanych zasobów należą ich sieci społeczne i zaangażowanie w życie wspólnoty, a także cechy przynależne tej wspólnocie jako całości - tożsamość i tradycja lokalna. Znajduje to odzwierciedlenie w mniej indywidualistycznych i bliższych dynamice życia codziennego metodach badawczych - wywiadach fokusowych i warsztatach diagnostycznych, a w jeszcze większym stopniu badaniach etnograficznych.

Trudno jednak nie zauważyć, że perspektywa zasobów nie zawsze przekłada się w dokumentach na rzeczywiście „demokratyczne” ujęcie aktywności kulturalnej. Musiałoby ono oznaczać odejście od hierarchizacji różnych form życia kulturalnego jako mniej lub bardziej pożądanych z punktu widzenia autorów diagnoz, samych instytucji lub „społeczności”. Tymczasem - co staraliśmy się podkreślić - zasoby uczestników często rozpatrywano pod kątem możliwości ich wykorzystania w instytucjonalnym obiegu kultury; dotyczyło to zwłaszcza różnego rodzaju zasobów indywidualnych, takich jak duża ilość wolnego czasu, uzdolnienia czy pasje, ale też zasobów międzyludzkich i wspólnotowych. Zasoby manifestujące się jedynie w prywatnych lub towarzyskich aktywnościach kulturalnych opisywano niekiedy jako „drzemiące” lub nie w pełni wykorzystywane. Tego rodzaju działania postrzegano też rzadko - jako świadectwo porażki instytucji, która nie potrafiła zainteresować mieszkańców swoją ofertą i w rezultacie „skazała ich” na kulturalną samodzielność.

Wynika z tego, że samo przyjęcie perspektywy zasobów nie wystarczy, aby w pełni dowartościować oddolne przejawy aktywności kulturalnej. Uważamy jednak, że nieprzypadkowo w tych spośród diagnoz, w których najpełniej opisano zasoby uczestników, położono też największy nacisk na pomocniczą rolę instytucji kulturalnych. Właśnie w tym punkcie najlepiej widać konsekwencje tej perspektywy dla planowania lokalnej polityki kulturalnej. Trudno wprawdzie liczyć na to, że zacznie ona odgrywać w najbliższym czasie dominującą rolę, ponieważ w wielu miejscach wiązałoby się to z radykalnym odejściem od status $q u o$ - „lokalnego imperializmu” instytucji i ich paternalistycznych relacji z uczestnikami. Trzeba też pamiętać, że wymóg diagnozowania potrzeb i monitorowania stopnia ich zaspokojenia często jest wpisany w założenia programów grantowych, z których można uzyskać dofinansowanie działań kulturalnych (np. w ramach Europejskiego Funduszu Społecznego - zob. Smykowski i Rosińska 2015: 202). Można jednak mieć nadzieję, że uzupełnienie perspektywy potrzeb o perspektywę zasobów doprowadzi do pogłębienia i urealnienia wiedzy na temat życia kulturalnego, a w rezultacie - do stopniowego przeformułowania misji instytucji kulturalnych. 


\section{BIBLIOGRAFIA}

Andersen, Lisa i Margaret Malone. 2013. All Culture Is Local: Good Practice in Regional Cultural Mapping \& Planning From Local Government, The CAMRA Toolkit, Sydney: UTS Press, http://hdl.handle.net/10453/24007 [21.01.2017].

Bachórz, Agata, Karolina Ciechorska-Kulesza, Sławomir Czarnecki, Martyna Grabowska, Jakub Knera, Lesław Michałowski, Krzysztof Stachura, Stanisław Szultka, Cezary Obracht-Prondzyński i Piotr Zbieranek. 2014. Punkty styczne: między kultura a praktyka (nie)uczestnictwa, Gdańsk: Instytut Kultury Miejskiej, http://www.repozytorium.ikm. gda.pl/items/show/108 [21.01.2017].

Bargielski, Michał i Karol Wittels. 2014. Obiegi kultury na Mazowszu, Warszawa: Mazowiecki Instytut Kultury, http://www.mazowieckieobserwatorium.pl/media/_mik/files/265/ raport-mik-02-best.pdf [21.01.2017].

Creative Cities Network. 2010. Cultural Planning Toolkit, British Columbia: 2010 Legacies

Now and Creative City Network of Canada, http://www.creativecity.ca/database/files/library/ cultural_planning_toolkit.pdf [21.01.2017].

Evans, Graeme. 2001. Cultural Planning: An Urban Renaissance?, London: Routledge.

Grogan, David, Colin Mercer i David Engwicht. 1995. The Cultural Planning Handbook: An Essential Australian Guide, Brisbane: Allen and Unwin.

Hawkes, Jon. 2001. The Fourth Pillar of Sustainability: Culture's Essential Role in Public

Planning. Common Ground, Melbourne: Cultural Development Network, http://www.culturaldevelopment.net.au/community/Downloads/HawkesJon(2001)TheFourthPillarOfSustainability.pdf [21.01.2017].

Krajewski, Marek i Agata Skórzyńska (red.). 2017. Diagnoza w kulturze, Warszawa: Narodowe Centrum Kultury, http://saek.pl/wp-content/uploads/2017/01/nck_diagnoza-w-kulturze_srodek.pdf [21.01.2017].

Maslow, Abraham. 2009. Motywacja i osobowość, thum. Józef Radzicki, Warszawa: Wydawnictwo Naukowe PWN.

Mennell, Stephen. 1979. Theoretical considerations on the study of cultural 'needs', „Sociology" 13(2): 235-257.

Mills, Deborah. 2003. Cultural Planning - Policy Task, not Tool, „Artwork” 55: 7-11.

Rutkowski, Roman. 1982. Diagnoza społeczna w działalności kulturalnej, Warszawa: Centralny Ośrodek Metodyki Upowszechniania Kultury.

Smykowski, Błażej i Agnieszka Rosińska. 2015. Diagnoza społeczności lokalnej dla celów animacji i aktywizacji, „Człowiek i Społeczeństwo” XXXIX: 197-2014.

Szatur-Jaworska, Barbara. 2014. Diagnozowanie w polityce spotecznej. Metody i problemy, Warszawa: Dom Wydawniczy ELIPSA.

Szlendak, Tomasz i Krzysztof Olechnicki. 2016. Raport z raportu o raportach o kulturze, http://www.beczmiana.pl/1158,raport_o_raportach_o_kulturze.html [21.01.2017].

Theiss, Maria, Marta Białek-Graczyk, Marta Olejnik, Łukasz Ostrowski, Tomasz Kasprzak i Marcin Jewdokimow. 2009. Zoom na domy kultury. Diagnoza domów kultury w województwie mazowieckim, Warszawa: Towarzystwo Inicjatyw Twórczych „e”, http://www. zoomnadomykultury.pl/data/files/raport_zoom.pdf. 


\section{NEEDS OR RESOURCES? APPROACHES TO CULTURAL ASSESSMENT IN POLISH MUNICIPALITIES}

The paper discusses selected results of a research project on cultural assessments in Polish municipalities. A distinction is drawn between two general approaches to participants in local culture and their relationship with public cultural institutions. The perspective of cultural needs effectively translates into assessing cultural preferences of participants and their expectations concerning the activity of public institutions. Such an approach implies a 'one-dimensional' concept of cultural needs and relegates cultural participants to the role of passive recipients. The perspective of cultural resources focuses on individual qualities and collective forms of capital conducive to cultural activity. This approach yields a more empowering picture of cultural participants as potential partners in public institutions and contributors to local culture.

Keywords: community cultural assessment, cultural needs, cultural resources of participants 